\section{Pontomedullary Listeriosis in Renal Allograft Recipient}

\author{
J. F. MAHONY, J. A. TAMBYAH, V. C. DALTON \\ W. H. WOLFENDEN
}

British Medical fournal, 1974, 2, 705

Infections with opportunistic organisms occur in renal allografit recipients on immunodepressive therapy. Such therapy suppresses the mechanisms responsible for homograft rejection-a function primarily of thymus-derived lymphocytes. In mice these cells are needed for resistance to listeria and an incidence of listeriosis in allograft recipients might be expected. We report here a case of Listeria monocytogenes septicaemia with non-meningitic pontobulbar involvement after renal transplantation.

\section{Case Report}

A 43-year-old man with renal failure due to excessive ingestion of analgesic powders, milk, and soluble alkali received a cadaveric renal allograft on $19 \mathrm{July,}$ 1970. Immunosuppression included a sixweek course of antilymphocyte globulin, azathioprine $200 \mathrm{mg}$ daily, and a dose of prednisone reduced to $20 \mathrm{mg}$ daily by 15 November 1971. His serum creatinine was then $1.2 \mathrm{mg} / 100 \mathrm{ml}$ and an ischiorectal abcess was drained. On 29 November after three days' fever and vomiting without abnormal signs, his cerebrospinal fluid was sterile and showed 27 lymphocytes and 16 polymorphs per $\mathrm{mm}^{3}$. The next day he developed oocipital headache, diplopia, and dysarthria. He was fully conscious, the neck was supple, and there was nystagmus to both sides, and skew deviation of the eyes on lateral gaze. The left corneal response was absent. There was left facial paralysis of lower motor neuron type, reduced palatal and pharyngeal movements on the left, and brisker tendon jerks with absent abdominal reflexes on the right side. There was loss of pain and temperature appreciation in the right arm and leg and cerebellar ataxia in the left arm and both legs. These findings indicated a lesion in the left lateral lower pons and upper medulla. The next day he developed drowsiness, dysphagia, and intercostal weakness, and he needed tracheostomy and respiratory assistance for six weeks.

On 30 November his leucocyte count was $7,800 / \mathrm{mm}^{3}$ with $83 \%$ neutrophils and his cerebrospinal fluid showed 255 polymorphs, 13 lymphocytes, and 34 red cells per $\mathrm{mm}^{3}$ with glucose content 55 $\mathrm{mg}$ and protein $83 \mathrm{mg} / 100 \mathrm{ml}$, but no organisms were seen or cultured. On 4 December blood cultures collected three days earlier grew $L$. monocytogenes. Treatment for presumed fungal meningitis was changed to benzylpenicillin $24 \mathrm{MU}$ and streptomycin $1 \mathrm{~g}$ daily, and his fever rapidly settled. Hydrocortisone $100 \mathrm{mg}$ and azathioprine $50 \mathrm{mg}$ daily were given intravenously until discharge.

By 8 December failuxe of conjugate ocular deviation to both sides, marked right-sided facial weakness, and bilateral palatal paresis had developed, indicating bilateral extension, and erythromycin $1.8 \mathrm{~g}$ daily was added to the treatment.

Immunology and Renal Unit, Sydney Hospital, Sydney, Australia

J. F. MAHONY, F.R.A.C.P., Physician

J. A. TAMBYAH, M.R.A.C.P., Registrar (Present appointment: Physician, Medical Unit III, Outram Road General Hospital, Singapore)

Renal Unit, Royal Newcastle Hospital, Newcastle Australia V. C. DALTON, M.B., B.S., Registrar

Department of Neurology, Sydney Hospital, Sydney, Australia W. H. WOLFENDEN, F.R.A.C.P., Honorary Physician
Antibiotics were changed on 18 December to methicillin $6 \mathrm{~g}$ and gentamicin $120 \mathrm{mg}$ daily for a further two weeks. The patient improved slowly and on 6 January 1972 facial, palatal, and ocular weaknesses were less marked though skew deviation, cerebellar incoordination, bilateral hypentonia, and right-sided dissociated anaesthesia persisted. He was discharged on 24 March 1972 but one year later still had an absent corneal reflex, coarse nystagmus to the right, left facial and tongue paresis, and bilateral cerebellar incoordination. Serum creatinine was $2.0 \mathrm{mg} / 100 \mathrm{ml}$ with prednisone $12.5 \mathrm{mg}$ and azathioprine $150 \mathrm{mg}$ daily.

\section{Discussion}

The central nervous system is usually affected in adult listeriosis, most commonly with meningitis (Gray and Killinger, 1966). Non-meningitic bulbar involvement is rare and only two cases have been recorded in English. The first, in a 55year-old farmer, was fatal and necropsy showed extensive necrosis and suppuration in the pons and medulla with microscopic haemorrhages, fibrinoid necrosis of the small vessels, and perivascular leucocyte cuffing (Duffy, 1964). The second patient, a 69-year-old man with rheumatoid arthritis treated with prednisone and corticotrophin, recovered after treatment with penicillin given before the diagnosis of listeriosis was made (Ford et al., 1968). The European literature described bulbar listeriosis as occurring in two phases. The first stage of headache, vomiting, fever, and mild leucocytosis lasted four to 10 days and was followed by the appearance of signs of pontobulbar involvement. Death from respiratory or cardiac failure occurred within a few days, often before the organism was identified. Usually the spinal fluid was sterile and diagnosis was made from blood cultures, as in our patient.

In both the cases of listeriosis after renal transplantation reported in English (case 2 of Medoff et al., 1971; Nirmul et al., 1971) the patients had meningitic listeriosis while on prednisone and azathioprine, and all three immunosuppressive agents commonly used have been implicated in its pathogenesis. Conticosteroids increase susceptibility to listerial infection in man (Gray and Killinger, 1966), azathioprine selectively suppresses $T$ cell function (Fournier et al., 1973), and antilymphocyte globulin also suppresses cellular immunity. In mice resistance to listeria is dependent on aotivated lymphocytes which are destroyed by antilymphocyte serum (Mackaness and Hill, 1969). Moreover, azathioprine given at the time of listerial infection irreversibly suppresses the immune response responsible for resistance (Tripathy and Mackaness, 1969).

Renal allograft recipients on these agents are susceptible to listerial infection. As therapeutic failure has been found with most antibiotics, despite the organism's usual sensitivity, prompt and prolonged administration of at least two antibiotics is desirable (Nihmul et al., 1971).

\section{References}

Duffy, P. E., Sassin, J. F., Summers, D. S., and Lourie, H. (1964). Neurology 14, 1067.

Ford, P. M., Herzberg, L., and Ford, S. E. (1968). Quarterly Fournal of Medicine, 37, 281.

Fournier, C., Bach, M. A., Dardenne, M., and Bach, J. F. (1973). Trans-

plantation Proceedings, 5, 523.
Gray, M. L., and Killinger, A. H. (1966). Bacteriology Reviews, 30, 309.

Gray, M. L., and Killinger, A. H. (1966). Bacteriology Reviews, 30, 309.
Mackaness, G. B., and Hill, W. C. (1969). Fournal of Experimental Medicine, $129,993$.

Medoff, G., Kunz, L. J., and Weinberg, A. N. (1971). Fournal of Infectious Diseases, 123, 247.

Nirmul, G., Glabman, S., Haemov, M., Leiter, E., and Burrows, L. (1971). New England fournal of Medicine, 285, 1323.

Tripathy, S. P., and Mackaness, G.B. (1969). Fournal of Experimental Medicine, 130, 1 